\title{
Value-based scenario planning: exploring multifaceted values in natural disaster planning and management
}

\author{
Andrea Rawluk $^{1}$, Rebecca M. Ford ${ }^{1}$ and Kathryn J. H. Williams ${ }^{1}$
}

\begin{abstract}
The multifaceted dynamics of values underpin many social-ecological challenges, but there are limited approaches for grappling with them. Participatory scenario planning can be a useful tool to explore and evaluate different approaches in natural disaster management. We developed value-based scenario planning as a general framework and process and applied it to the context of bushfire management in Victoria, Australia. From our application, three scenarios resulted: developing self-reliant people and communities; a safe society: separating people and fuel; and living with nature and bushfire. We found that values could guide the development of relatable scenarios and that value-based scenarios supported the understanding of complex relationships between abstract and concrete values and natural disaster management and planning. We found that scenarios led people to think outside of their area of comfort and fostered reflection, discussion, and consideration for how to bridge value differences. Future applications of value-based scenarios could support communication between decision-making agencies and the public in the face of uncertainty, complexity, and value conflict.
\end{abstract}

Key Words: bushfire; participation; participatory scenario planning; value-based scenarios; values; value tensions

\section{INTRODUCTION}

Values and value conflicts are central to sustainability challenges in social-ecological systems (Jones et al. 2016) such as planning for and protecting against natural disasters (Graham et al. 2013). Alongside, there is a growing call to holistically understand the dynamics of how the values of the public can be affected and protected through planning and management (Denhardt and Denhardt 2000, Moritz et al. 2014, State Government Victoria 2015). Normative intentions to incorporate values in policy provide a way for agencies to navigate the complexity of socialecological challenges (Ford et al., unpublished manuscript). However, the values that shape decision making and conflicts can be abstract, multifaceted, and challenging to translate into tangible narratives for members of the public, government agencies, and other stakeholders to visualize and grapple with.

Participatory scenario planning (PSP) is a collaborative process that supports engagement and conversation with key stakeholders (Palomo et al. 2011) through creating tangible narratives on complex issues. PSP fosters complexity thinking among participants (Oteros-Rozas et al. 2015) to generate comparable future states that may be plausible or ideal (Malinga et al. 2013). PSP has multiple forms and uses, including for ecosystem services and environmental management (e.g., Peterson et al. 2003, Evans et al. 2006, Patel et al. 2007, Malinga et al. 2013), environmental decision making and strategic planning (Biggs et al. 2007, Mitchell et al. 2016), climate change adaptations (Carlsen et al. 2013, Nieto-Romero et al. 2016), and exploring futures of hope in the Anthropocene by drawing on contemporary "seeds" of change (Bennett et al. 2016). However, although values and value judgments are implicitly at the heart of the conversations and challenges explored through participatory scenarios, PSP has, to date, fallen short in explicitly grappling with values (Carpenter et al. 2005). There is a need to "explicitly discuss and present valuechoices in the scenario generation ... value-laden discussions are often emotionally charged and require substantial efforts to manage in an effective participatory process" (Oteros-Rozas et al.
2015:44). Values are part of the complexity of social-ecological challenges, and there is an opportunity and need for better grappling with them in PSP.

We, the authors, address two related challenges: (1) how values can be more explicitly drawn on in participatory scenarios and (2) how participatory scenarios can help consider the challenges of values and value conflicts. We describe a participatory, valuebased scenario planning approach that draws on the strengths of PSP to address value challenges explicitly. We then illustrate this approach by applying it in a case study of bushfire planning and management in Victoria, Australia. Finally, we use social data to evaluate the approach from the perspective of scenario development participants and members of the public who were later interviewed.

\section{Grappling with values and looking to participatory scenario planning}

Values are challenging to consider in planning and management because they are multifaceted and often abstract. They are a way to understand what is important to communities (Brown and Reed 2000, Graham et al. 2013) and can be abstract drivers of conflict and public responses to planning and management (Ford et al. 2014). Values for forests and other natural areas are diverse and often contested (Ford et al. 2014) and can shape climate change adaptation pathways (O'Brien 2009). At the most abstract level, values are ideas or principles for living (Brown 1984, Schwartz 2012); at the most concrete level, value is placed on relatively tangible objects or entities (Rawluk et al. 2017). These more abstract and concrete values are linked through relations of "valuing." We use the term valued attributes to express characteristics and outcomes that give value to entities, for example, meeting needs for human health and relationships or personal identity (Kendal et al. 2015, Rawluk et al. 2017). Members of the public hold diverse and contrasting values in relation to natural disasters that are likely to influence their views on management and on what should be protected and how 
Fig. 1. Conceptual framework of values from abstract to concrete: core values, valued attributes, and values entities. This conceptual framework, and the accompanying descriptions, is adapted from Rawluk et al. (2017).

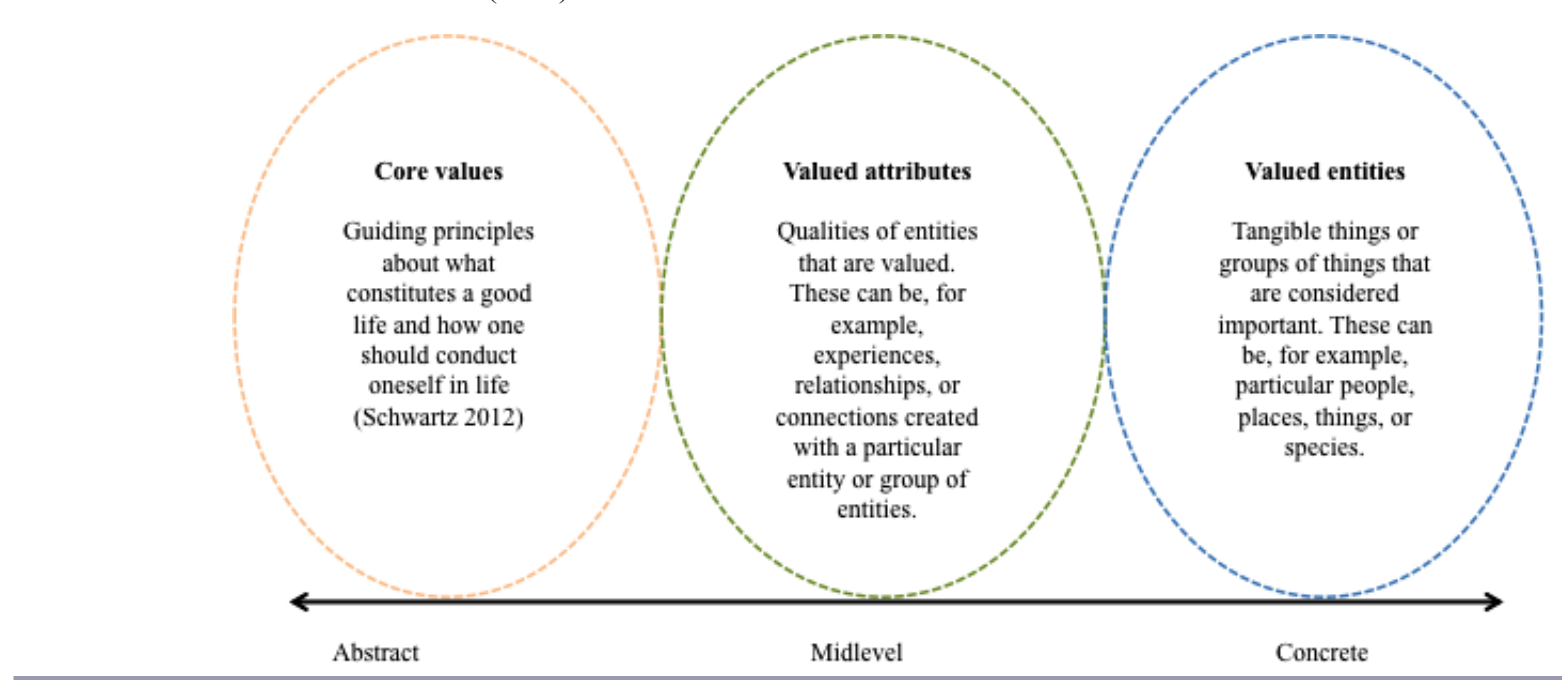

(Rawluk et al. 2017). These include more specifically the valued entities, i.e., people/homes/health facilities, infrastructure, domestic animals, natural places/wildlife, heritage objects, and places of work/education and welfare support; valued attributes, i.e., natural and experiential attributes of the landscape, human health and relationships, going about daily life, animal welfare, personal history and identity, and livelihoods, economies, and productive capacity of the landscape; and core values, i.e., benevolence, universalism-human altruistic, universalismbiospheric, security, and self-direction (Fig. 1). Although Rawluk et al. (2017) identified the range of values that can be affected by natural disaster, there has been little exploration of how these multifaceted values can help shape alternative management approaches.

Although values are recognized as important in decision making, there are few explicitly value-based approaches, and those that exist tend to be very structured (e.g., Gregory and Keeney 1994). PSP can assist with exploring the complexity of value-based challenges because it can bring together diverse stakeholder perspectives to these challenges. Often expressed through narratives, participatory scenarios are relatable to a breadth of people (Soliva 2007) and help them grapple with how intangible forces can shape complex outcomes of decision making (Rotmans et al. 2000). These scenarios use qualitative data such as local observations, perspectives, knowledge, and local literature (Ramírez and Selin 2014). There is freedom to explore relationships in the scenarios based on personal experience and intuition (Sheppard 2005), such as the link between abstract and concrete values, and management practices or actions. Although participatory scenarios have been used to consider values implicitly through indirect social drivers such as community involvement and exclusive or inclusive forms of governance (Low Choy et al. 2012), they have yet to incorporate values in an explicit way (Oteros-Rozas et al. 2015).

PSP enables the creation of scenarios that are meaningful to members of the public, which is critical for exploring value-based challenges. Stakeholders, practitioners, and/or members of the public draw on their combined experience in a "process of social construction of various possible futures" (Larsen et al. 2011:414) through reflecting on current management, exploring possible futures, and articulating ideal management actions (Kok et al. 2006). They provide an opportunity to talk about complex or uncertain topics, which can create both discomfort (Ramírez and Selin 2014) and meaningful reflection and learning (Larsen and Gunnarsson-Östling 2009). PSP can provide a way for members of the public to engage in a meaningful discussion about values and value conflicts that might be otherwise too abstract and not relatable.

\section{GENERAL OUTLINE OF THE VALUE-BASED SCENARIO PLANNING PROCESS}

We outline an approach that we call value-based scenario planning to explore key value tensions in social-ecological planning and management contexts. We define value-based scenarios as tangible imaginings of how abstract values might be expressed in planning and management for a social-ecological context. Drawing on the strengths and approach of PSP, we develop a general process that can be applied in different contexts to enable value tensions to be tangibly explored and robustly compared and that creates scenarios that are relatable to members of the public.

Our approach builds on previous ones that use a $2 \times 2$ matrix (Curry and Schultz 2009) to structure the development of contrasting scenarios (Carpenter et al. 2005). Previous drivers of the matrix have been factors such as globalized or regionalized governance and environmental management that was proactive or reactive (Carpenter et al. 2005), or governance type and community responsibility (Low Choy et al. 2012). In our approach, we instead engage the theoretical perspective that core values shape perceptions about social-ecological challenges (Ford et al. 2009), and we use core values as drivers in a 2 x 2 matrix technique (Fig. 2). 
Fig. 2. Value-based scenario planning framework based on the arrangement of contrasting values. The general framework enables those applying it to draw on different forms of abstract values.

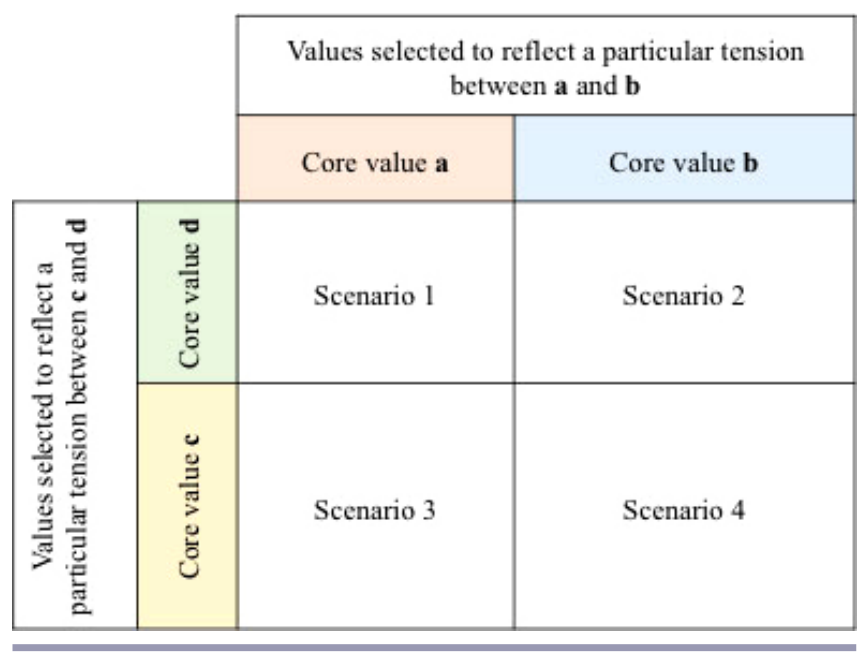

In the description that follows, we outline value-based scenario planning in four general steps that could be applied in many contexts. We expect these to be applied as a reflective practice adapted to the context, rather than as a replicable method. For example, some steps may be more important in some contexts than in others or may be applied iteratively in some situations. They are intended as guideposts of what to consider and reflect on in developing a set of value-based scenarios.

\section{Step 1: identify core value-based tensions that establish the} framework

The design of any value-based scenario building process should respond to the particular issues and actions for which scenarios are to be developed, as well as the ways in which people apply their values to those issues. General frameworks of core values such as Schwartz's (2012) theory of basic values or van Egmond and de Vries's (2011) value orientations for sustainability can provide a starting point for selecting a pair of value tensions for a value-based scenario framework. However, different core values tend to be evoked in different contexts, and different pairs of values may be in tension. The identification of values and value tensions and how these influence considerations about management must be grounded in robust social science research. Core values and tensions among them may already be known for the context or could be elicited from participants using methods such as laddering interviews (Bourne and Jenkins 2005, LópezMosquera and Sánchez 2011, Ford et al. 2017) with members of the public. Core value tensions, once identified, are organized into the value-based scenario matrix (Fig. 2).

Step 2: identify the general scenarios that can be developed within the framework through the overlap of core values and describe in more tangible terms as a starting point for scenario development The quadrants of the framework will suggest multiple value combinations, for example, self-direction and benevolence, around which scenarios could be built; however, not all may make interesting scenarios, or there may be potential for more than one interesting scenario in a single combination. Therefore, it will be important to identify the areas of core value overlap in the framework and reflect on the general kinds of scenarios that could be developed. This will depend on the context and can be explored through pretesting. The identified core value combinations are abstract. Although this opens many possibilities for creative scenarios, some participants may find it difficult to translate these values into more tangible values and management actions. It can be helpful to provide people with suggestions about tangible values that are known to be associated with the core values, while also emphasizing that the core values are the main starting point. Researchers, or those facilitating the scenario development, will need to also consider issues such as spatial scale and scope of the scenarios in relation to the context. For example, they need to consider at what scale participants are likely to think about the issue and whether actions to address the issue are generally applicable or specific to a particular geographic location. In addition, scenario development facilitators need to start to consider how the scenarios are likely to be presented, such as whether this will include information about outcomes in relation to what is valued and, if so, who will provide that information and how.

Step 3: develop scenarios as part of a participatory process Facilitators then engage an appropriate participatory scenario development process with desired participants. Who these desired participants are could vary depending on the aim of the scenario development process. For example, it could be suitable to have participants be members of the general public or from key stakeholder groups. The scenario development process can be tailored to the capabilities of the participants and needs for the scenarios. For example, one option might be that participants are organized into small groups and each group develops one or more scenarios congruent with the values of people in the group. Alternatively, it may be more suitable for all participants to develop each of the scenarios together. In deciding the appropriate way for developing scenarios in their circumstance, facilitators need to be able to have the most meaningful scenarios developed with an awareness of the time constraints, capacities, level of interest, level of value conflict, and power dynamics of the participant group. If scenario development occurs in multiple small groups, group members will be in the best position to explore the core value combinations of their allocated scenario if they share those values, so this should be considered in participant selection and group formation.

Drawing on the most appropriate process, participants are then supported to develop scenarios. Drawing on the framework as a guide, each group of participants is asked to articulate their allocated scenario(s) based on a general context, the core value combinations, and any suggestions to help link these to more tangible values. For example, the core value of self-direction is the principle that individual agency and decision making are important.

If participants are considering how self-direction might shape a planning or management scenario, they will need to consider how that will be expressed in a management action and where that action will occur and when. In the case of managing risks from natural and human-caused disasters, a management action that 
involves self-direction might mean individuals/families make decisions about evacuation from their homes before or during events, rather than the decisions being made by state authorities.

Step 4: refine, find narratives in, present, compare, and reflect on scenarios with participants and ensure they are relevant to the target audience

Nordström et al. (2010) suggest that in creating a set of discrete alternatives, it is best that there not be too many options. The facilitators/researchers can refine the scenario set by comparing the developed scenarios, and if there is significant overlap between any, they can be combined into one scenario. The ideal is to make a set of discrete scenarios that describe the relevant value space parsimoniously. Participants can be asked to reflect on the final set of scenarios and change them as needed. Scenarios are then shaped by the researchers (Enfors et al. 2008) or by other participants, if there is scope, into brief coherent narratives suitable for wider communication. The facilitators/researchers need to consider how the scenarios can be best presented for the intended audience and use. For example, in some instances narrative descriptions alone might be most appropriate, and/or in others, expert ratings of scenarios might add additional information suitable to the audience and context.

\section{APPLYING VALUE-BASED SCENARIO PLANNING: A CASE STUDY OF BUSHFIRE PLANNING AND MANAGEMENT IN VICTORIA, AUSTRALIA}

\section{Case study context}

We draw on bushfire as a frequent and recurring natural disaster, also referred to as wildfire, in Victoria, Australia. Climate change scenarios predict an increase in the frequency and scale of bushfires (Lindesay 2003), which can have catastrophic socialecological impacts. Although fire has regularly and devastatingly occurred in Australia's history since settlement, with approximately 25 large-scale events, the most recent was Black Saturday on 7 February 2009, which took the lives of 173 people, destroyed 2000 houses, and left more than A\$3.5 billion in damages (O'Neill and Handmer 2012, Whittaker et al. 2013).

Bushfire policy and management is complex. In Victoria, it is launched at the state level and is interpreted and implemented at landscape and local scales. At the landscape scale, teams of agency staff identify what is important to the landscape that should be protected, generally termed as assets such as houses, power plants, heritage sites, or dams. At the time this research was undertaken, the state was organized into seven bushfire risk landscapes, where teams interpreted and applied state-level objectives to their local landscapes through a code of practice (Department of Sustainability and Environment 2012). Planned burning, to reduce the amount of vegetation that can burn in a fire, i.e., "fuel load," is the principle management technique, and at the time this research was undertaken, a policy target required that $5 \%$ of public land in Victoria be burned annually to reduce bushfire risk (Parliament of Victoria 2010). This management action is contentious (Gill 2012), and there are alternative management actions that may be preferable to some members of the public, including education and evacuation.

Value tensions exist around what is considered important for planning and management and its implementation. Narratives of bushfire and bushfire management show contrasting ideas of what is important and beliefs about management action effectiveness. Whittaker and Mercer (2004) identified three public discourses that considered the following: (1) the environment to be most important and bushfire as natural, (2) rural regions as most important and that must be protected from fire that is unnatural, and (3) rural regions are under threat of bushfire from poor management.

People have differing beliefs about planned burning as a management action, including that it is ineffective and damaging to the environment, effective at protecting assets, and important but unclear in its effectiveness (Altangerel and Kull 2013). Further, Bosomworth (2011) found two coexisting bushfire management frames in an organization: emergency management to prioritize human life and sustainability recognizing multiple values, including the environment. Planning for and management of bushfire is shaped by multiple, often contradictory values, with few transparent ways of reconciling them. Although these discourses are helpful to understanding social challenges with bushfire and its management and may implicitly reflect value differences, they are not explicitly linked to values.

Victorian bushfire policy has begun to shift toward more transparently considering multiple public values in broad strategic planning and community-based implementation and decision making. Government and agencies seek to develop capacity in meaningful public engagement and to incorporate public values into planning and policy for bushfire (Department of Environment Land Water and Planning 2015), but they are currently limited in their capacity to do so. This creates an opportunity for exploring ways of transparently grappling with value-based decisions, such as through the use of scenarios.

\section{Application of value-based scenario planning}

We illustrate the four general steps of value-based scenario planning through describing the detailed process by which we applied them to the context of bushfire planning and management in Victoria, Australia. We sought scenarios that could be meaningful and relatable to all members of the public and that could be used in a survey or possible community engagement processes. We held a series of three workshops between June and August 2016. Data were collected during the workshops through audio-recording, written notes by researchers, and responses written by participants. All data were handled using NVivo 10. Data were analyzed using thematic content analysis (Boeije 2010). Key themes identified were the tensions, challenges, and opportunities in using the value-based scenario framework, as well as participant learning.

Step 1: identify core value-based tensions that establish the framework

Drawing on Schwartz (2012), Rawluk et al. (2017) identified a breadth of core values that can be affected by bushfire and bushfire management. To structure a value-based framework for this issue (Fig. 2), we further analyzed qualitative interview data that were collected for Rawluk et al. (2017) and identified key tensions between core value that would provide a compelling and relatable basis for scenario development. The previously collected data (Rawluk et al. 2017) were 30 interviews carried out with members of the public, to identify what was important to members of the Victorian public and why. The number of interviews reflected saturation in that with 30 interviews we were 
confident that the values identified were reflective of the public (Mason 2010). We used qualitative content analysis to identify the values present in the interview data (Boeije 2010). The decision on which value tensions to include in the scenario development came from a combined consideration of (1) values and value tensions that frequently appeared in the analysis of our data, (2) value polarities identified in Schwartz (2012) that informed our data analysis, and (3) compelling and relatable value tensions that could be explored by members of the public.

First, benevolence and universalism (human altruistic and biospheric) contrastingly focus on what to protect, one's immediate family, home, and friends versus all of society or the entire integrity of the natural world. Second, self-direction and security contrast in how valued entities and attributes are protected and who acts to do this. Self-direction is the importance of freedom to make decisions for oneself. Security, in this bushfire context, conversely suggests that the government should protect what is socially important from harm (Rawluk et al. 2017). These contrasting values underpin much of the conversation and challenges faced at the interface between natural disaster policy/ planning and the public, yet there has not been a coherent way for decision-making bodies and communities to articulate or compare these values in policy and planning.

We drew on these four contrasting core values, i.e., universalism, benevolence, self-direction, and security, and organized them in a 2 × 2 matrix framework to structure the development of distinct and comparable scenario narratives (Fig. 3). We identified a scenario to be developed for each overlapping value combination. In the bushfire context, two of these values, i.e., benevolence and universalism, orient to what is protected, and two of them orient to how what is important is protected. When they combine, they form different scenario narratives on what is protected and how to explore these key tensions.

Fig. 3. Application of the value-based scenario framework to bushfire and bushfire management in Victoria, Australia. We drew on research that indicated four core values (Schwartz 2012) are involved in value tensions for this context. The core values used in the application of the framework are benevolence, universalism, self-direction, and security.

\begin{tabular}{|c|c|c|c|c|}
\hline & \multicolumn{3}{|c|}{ Values: what is protected } \\
\hline & & \multirow[b]{2}{*}{$\begin{array}{l}\text { Benevolence } \\
\text { protecting family, } \\
\text { neighbors, local } \\
\text { community, personal } \\
\text { home, etc. }\end{array}$} & \multicolumn{2}{|c|}{ Universalism } \\
\hline & & & $\begin{array}{l}\text { Human altruistic } \\
\text { protecting all that } \\
\text { constitutes human } \\
\text { sociesty (e.g., human life } \\
\text { and welfare, daily life } \\
\text { practice, infrastructure, } \\
\text { efc.) }\end{array}$ & $\begin{array}{l}\text { Biospheric } \\
\text { protecting the integrity of of } \\
\text { the natural world and } \\
\text { ecological systems, ahbititat. } \\
\text { and particularly flora and } \\
\text { fauna species, etc. }\end{array}$ \\
\hline \multirow{2}{*}{ 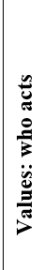 } & $\begin{array}{l}\text { Self-direction } \\
\text { Individuals, local } \\
\text { groups, } \\
\text { communities taking } \\
\text { action }\end{array}$ & Scenario la & $\begin{array}{l}\text { Not developed as } \\
\text { considered an } \\
\text { unlikely combination } \\
\text { of values }\end{array}$ & Scenario $2 b$ \\
\hline & $\begin{array}{l}\text { Security } \\
\text { Government and } \\
\text { society taking } \\
\text { action }\end{array}$ & Scenario $1 b$ & Scenario 2a & Scenario $2 \mathrm{c}$ \\
\hline & & & & \\
\hline
\end{tabular}

After we developed the framework based on the main value tensions, we realized that a further tension within the universalism core value was also important to scenario building in the bushfire context. In environmental issues, the broad universalist concern for society and the natural world (Schwartz 2012) has two distinct components, universalism-social altruistic and universalismbiospheric, which can be in tension where actions to protect one component affect the other. This distinction was evident in some interviews (Rawluk et al. 2017) and could lead scenario builders in different directions. This led us to expand the framework to identify six potential scenarios (Fig. 3).

Step 2: identify the general scenarios that can be developed within the framework through the overlap of core values and describe in more tangible terms as a starting point for scenario development As a first step to identifying the general scenarios, we considered the geographic scale at which our bushfire scenarios should be built. Scenarios can be tied to particular geographic locations such as an area of public land that is of broad interest to a range of people (e.g., Smith et al. 2012). In the bushfire context, we had learned that most people identified their own homes and the people close to them as important entities that could be affected by bushfire (Rawluk et al. 2017). Some people also described natural attributes of places as important, but we reflected that if a geographically defined scenario did not include a person's home, it would be difficult for them to relate to it. We chose instead to develop generic scenarios, composed of general management actions that could be applicable in different places, as a way of ensuring the scenarios would be broadly relevant to people in the bushfire context.

To explore the scenario building process and the potential of these six scenarios, we conducted a pretest of the process with a convenience sample. This was done a few weeks prior to the first workshop to see how participants were able to translate abstract values into tangible values and management actions in scenario development. The pretest suggested that one of the six scenario combinations, universalism-social altruistic and self-direction, was unlikely in the bushfire context, where self-direction was understood primarily as freedom to undertake bushfire-related actions on one's own property, rather than for the wider society. We decided not to build this scenario, which left five identified for scenario development (Fig. 3).

Pretesting also showed that an instruction to build a scenario based on a combination of two core values led to detailed sense making of connections between less tangible and tangible values, and management actions. Although this could be an invaluable part of the scenario building process, it was also time consuming and required the interest and capacity to be able to grapple with the abstractness and complexity of values and management actions. However, in our case, participants were members of the public who had limited time available for scenario development workshops and no experience working with the terminology or concepts of values. In response to these aspects of our participants and workshop process, we chose to provide scenario builders with suggestions for valued entities, valued attributes, and management actions that we knew were related to the core values based on our earlier research. To make these suggestions, we further analyzed data that were used to develop Rawluk et al. (2017). For example, we identified that for the core value benevolence, human health and well-being (valued attributes) and 
family members and pets (valued entities) were considered important. For the core value of self-direction, interview data showed that people cared about how they were able and allowed to respond during a bushfire, such as choosing whether to evacuate from their homes, when, and how, i.e., that roads were not closed.

The pretest led us to make the decision to present the scenario builders in workshops with not only the core value-based framework, but also some suggestions for what to consider for a particular scenario, for example:

Scenario 1 A (self-direction and benevolence): people act independently to protect their own family, friends, and people they know

\section{Examples of what is important:}

- My family (life, health, and safety)

- The family home and property

- My friends

- My animals

- My garden

- My neighbors

Who takes action:

- Individuals

- Families

- Small local groups, e.g., Country Fire Authority volunteers

\section{Step 3: develop scenarios as part of a participatory process}

We decided to use a workshop/focus group series for the participatory scenario development process (e.g., Kok et al. 2006, Malinga et al. 2013). We recruited 11 participants who were (1) collectively likely to represent a breadth of value orientations at the workshops; (2) residents of the case study landscape, east of Melbourne; and (3) able to think creatively and explore a range of possible management scenarios as opposed to focusing on their own priorities. These participants ranged in age from 41 years old to mid-70s. Some had experience with bushfire, and others did not. They came from across periurban and rural areas of the case study landscape. Five participants were women, and 6 were men, from a breadth of employment backgrounds; for example, they included individuals who were retired, an accountant, an environmental officer, an artist, an engineer, and a farmer.

To as best as possible reflect an ability to think creatively, we preinterviewed potential participants and explained that this is what we were seeking and asked if they would be willing to participate with this requirement. Two local members of bushfire agencies (the Department of Environment, Land, Water and Planning and Parks Victoria) attended the workshops to answer participants' questions and observe. These members were selected by their supervisor for being open minded, able to relate to the perspectives of community members and to social context more broadly, while having excellent listening skills and significant experience in the bushfire planning context.

In workshop 1, we drew on and adapted the laddering method outlined previously to elicit participant values that can be affected by bushfire to have people individually identify their values. Although the breadth of values drawn on in the research was preexisting from Rawluk et al. (2017), identifying workshop participant values helped us to explain what we meant by values, ensure that a breadth was reflected in the participants, and categorize and share their values as a group compared with the broader set (Rawluk et al. 2017). It further enabled us to see that the four different core values in the value-based framework were present in the workshop participants, and it enabled us to group participants according to their values. Participants articulated how they thought bushfire risk could be managed around their own homes and landscapes. This resulted in a long list of potential management actions, including some beyond those typically considered by land management agencies that might be included in scenarios to be developed. Participants identified their most important indicators for bushfire management outcomes from the researcher-developed list of 24 indicators described previously.

Between workshops 1 and 2, we organized the compiled list of management actions in relation to the two core values underpinning who acts, i.e., self-direction and security (Fig. 4). For example, the management action "planning where people live" could be expressed in the self-direction core value as individuals/families choosing where to live, while taking into account their age and physical means. Through the security core value, this same management action could be expressed as the government buying back blocks in fire prone areas. This provided an organized menu of management actions for scenario development.

In workshop 2, we explored the value-based scenario framework with participants and asked them to build scenarios. Participants were organized into two groups to develop scenarios, with group members selected to have core values overlapping with those of the scenarios they were building. One group built two, and the other group three scenarios considering the four questions: What is important, e.g., biospherism, benevolence, universalism? What would be protected and not? Why would these be protected and not? How would these be protected and not, drawing on the scenario suggestions developed after our pretest and the list of management actions developed after workshop 1, e.g., selfdirection or security? The researchers facilitated the process of scenario development. Participants were asked to reflect on the values that were expressed in the scenario and not simply their own values.

In workshop 3, participants reflected on scenarios they developed in workshop 2 and discussed how they wanted these to be changed or improved. Bushfire management can be controversial, and to foster individual reflection and responses, we provided participants with a short questionnaire. They rated the acceptability of each of the scenarios on a scale of 1-7 and explained their rating. To end the questionnaire, we asked participants to individually write their ideal bushfire management scenario in terms of what is important, who acts to protect, and what are the primary and secondary management action(s). 
Fig. 4. Organization of examples of management actions related to selected core values. The information in this table was gathered in workshop 1 and used in workshop 2.

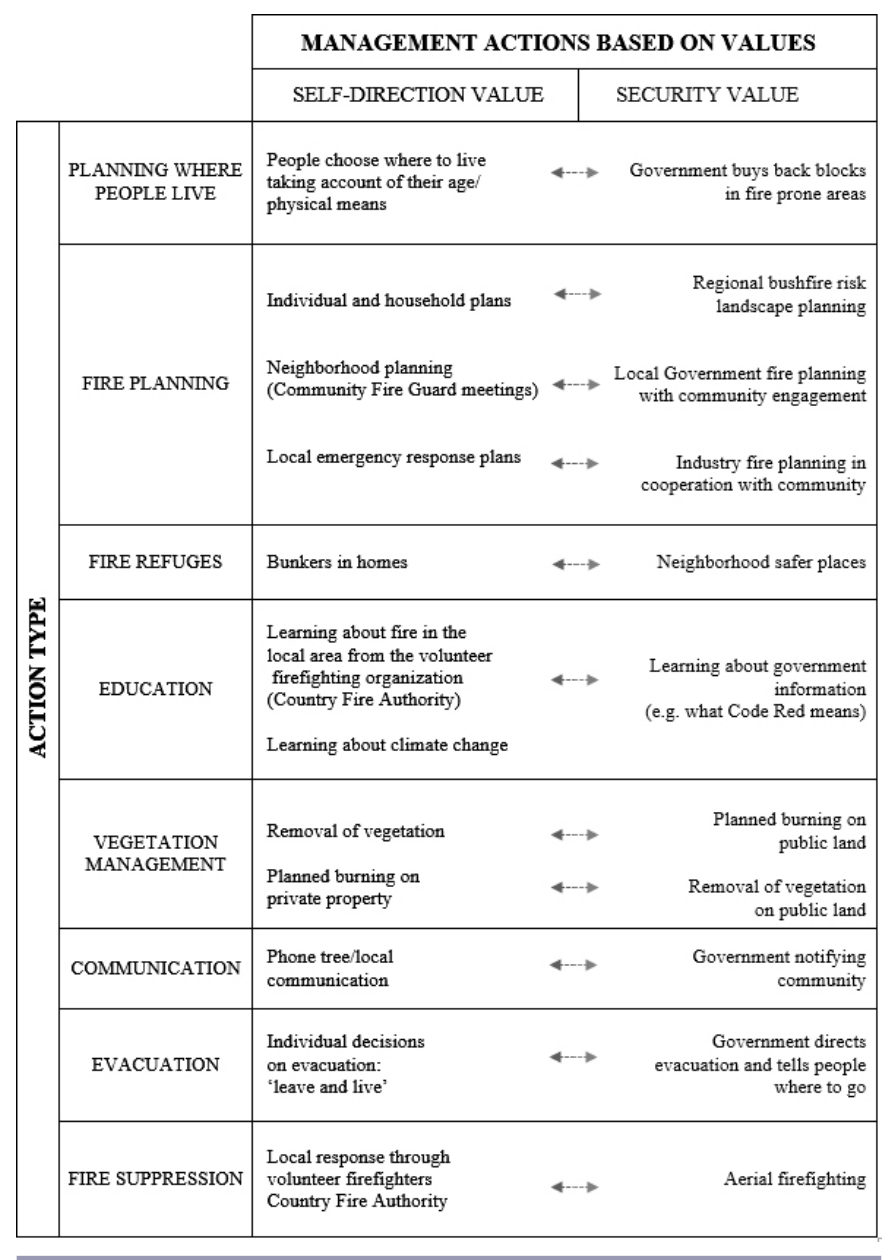

Step 4: refine, find narratives in, present, compare, and reflect on scenarios with participants and ensure they are relevant to the target audience

When we compared the resulting five scenarios in terms of the values, management actions, and who acts, we found that certain scenarios were actually quite similar to one another. Scenarios $1 \mathrm{~b}$ and $2 \mathrm{a}$ contained similar ideas of what to protect (family and society), by whom (society), and how to protect it, e.g., limiting development in high-risk areas. We also found similarities in scenarios $2 \mathrm{~b}$ and $2 \mathrm{c}$, which both focused on biospheric universalism but differed in terms of who acted to protect the environment. Participants included similar management actions in both, whereby government support was needed to allow citizens to protect the environment through local environmental groups, for example. To achieve a discrete set of scenarios, we combined some scenarios and, through this process, refined the original five scenarios from workshops to three for presentation (Fig. 5).

We named the scenarios to convey the key values and management actions that underpinned them and reflected some of the terminology used by participants. This provided us with a diverse scenario set that described a breadth of approaches to bushfire management related to the range of core values in the general public.

The intended audience for our scenarios was primarily members of the public and to some extent government agency staff who might use the scenarios in their work with communities. For this scenario development process, we chose to present scenarios primarily through narratives that would resonate with members of the public. To this end, we used some of the terms participants used in workshops to describe management. We also represented each scenario with an image to help make it relatable. We also chose to include a small number of indicators rated by experts in aspects of bushfire planning. This is not an essential part of narrative valuebased scenarios, but indicators can encourage careful engagement with the consequences of drivers of change in scenarios (Xiang and Clarke 2003). In the context of bushfire management in Victoria, both expert and local knowledge are considered important in decision making (State Government Victoria 2015), and the inclusion of expert-rated indicators with scenario narratives was thought to encourage exploration of these different forms of knowledge about bushfire management.

The process we used to identify indicators to present with the scenarios was complex and is largely beyond our scope, so we sketch it only. First, through the interviews conducted for Rawluk et al. (2017), we had identified a long list of socially relevant indicators using a method based on the psychological concept of cues that has been described in detail elsewhere (Ford et al. 2017). This produced a long list of more than 60 indicators that reflected how people might know about values affected by bushfire and its management. These indicators were not all able to be estimated, so in discussion with agency staff, a shorter list of 24 indicators was identified, which we believed were socially relevant and they believed could be estimated. These 24 indicators were then presented at the first workshop, and participants were each given 10 stickers to allocate to the indicators on which they would most like to judge scenarios. This helped us to develop a refined list of 9 indicators for expert rating. We asked local experts to qualitatively rate the scenarios on the indicator(s) for which they had expertise. These experts included government agency staff, academics, and practitioners that were not researchers on the project and were identified as having specialist knowledge on particular indicator(s). Scenarios were first presented and discussed with the experts, who then rated them in terms of a qualitative judgment of high, medium, and low. Following rating, we further reduced the number of indicators to those that were important to the greatest number of workshop participants and interviewees, and those for which we had most confidence in the expert ratings. These final four indicators are protection of human lives; protection of homes; integrity of ecosystems, flora, and fauna; and community selfreliance. As stated previously, in our application of the value-based scenario framework, we were looking to create scenarios that could be later considered by all members of the public through a survey and/or as a community engagement tool. The ratings of the four indicators provided succinct expert information about the outcomes of the scenarios, which could be interpreted by members of the public and considered in relation to the narrative descriptions based on local knowledge.

At the time of writing, the scenario set had not yet been applied to a practice-based context, but we identified that it would have 
Fig. 5. Three refined scenarios resulting from the participatory development process in workshops.

\begin{tabular}{|c|c|c|c|}
\hline & $\begin{array}{l}\text { DEVELOPING SELF- } \\
\text { RELIANT PEOPLE AND } \\
\text { COMMUNITIES }\end{array}$ & $\begin{array}{l}\text { A SAFE SOCIETY: } \\
\text { SEPARATING PEOPLE } \\
\text { AND FUEL }\end{array}$ & $\begin{array}{c}\text { LIVING WITH } \\
\text { NATURE AND FIRE }\end{array}$ \\
\hline $\begin{array}{c}\text { KEY VALUES } \\
\text { WHAT IS TOBE } \\
\text { PROTECTED }\end{array}$ & $\begin{array}{l}\text { Family, friends, home, } \\
\text { animals, businesses }\end{array}$ & $\begin{array}{l}\text { Human life and welfare, } \\
\text { property, infrastructure, } \\
\text { landscape, economies as } \\
\text { well as family, friends, } \\
\text { home, animals, businesses }\end{array}$ & $\begin{array}{l}\text { Trees, rivers, wildlife, } \\
\text { habitat, beauty, } \\
\text { ecosystems, parks }\end{array}$ \\
\hline $\begin{array}{l}\text { KEY VALUES } \\
\text { WHO ACTS }\end{array}$ & $\begin{array}{l}\text { Individuals, families, and } \\
\text { small local groups }\end{array}$ & $\begin{array}{l}\text { Government at all levels } \\
\text { and large organizations }\end{array}$ & $\begin{array}{l}\text { Governments, individuals, } \\
\text { and local groups act. }\end{array}$ \\
\hline $\begin{array}{l}\text { MANAGEMENT } \\
\text { ACTIONS }\end{array}$ & $\begin{array}{l}\text { Individual education about: } \\
\text { informed decision making } \\
\text { about where to live; how to } \\
\text { plan and prepare, including } \\
\text { evacuation decisions; risks in } \\
\text { local area; understanding of } \\
\text { personal limits; not to expect } \\
\text { government to tum up; real } \\
\text { experience of fire: noise, } \\
\text { scary; costs of recovery phase, } \\
\text { mental illness, etc. } \\
\end{array}$ & $\begin{array}{l}\text { Limit development in high } \\
\text { risk areas, e.g., through } \\
\text { planning scheme rules, } \\
\text { information provided by } \\
\text { estate agents, buybacks. } \\
\text { Vegetation management } \\
\text { (planned burning or } \\
\text { clearing) to protect assets } \\
\text { that are valued by } \\
\text { communities. }\end{array}$ & $\begin{array}{l}\text { Government, local groups, } \\
\text { and individuals are well } \\
\text { resourced to manage } \\
\text { ecosystems on public and } \\
\text { private lands. } \\
\text { Planned burning by } \\
\text { government and local } \\
\text { groups primarily for } \\
\text { ecosystems and education, } \\
\text { secondary focus on asset } \\
\text { protection. }\end{array}$ \\
\hline $\begin{array}{l}\text { MANAGEMENT } \\
\text { ACTIONS }\end{array}$ & $\begin{array}{l}\text { Bunkers and community } \\
\text { refuges } \\
\text { Individuals manage own } \\
\text { vegetation. } \\
\text { Evacuation nonmandatory } \\
\text { Neighbors and family check } \\
\text { on vulnerable people. }\end{array}$ & $\begin{array}{l}\text { Communicate about } \\
\text { approaching fires: remove } \\
\text { mobile phone blackspots; } \\
\text { use media to provide } \\
\text { information. } \\
\text { Improve road system to } \\
\text { make evacuation easier, } \\
\text { plan and practice } \\
\text { evacuation and provide } \\
\text { community refuges. }\end{array}$ & $\begin{array}{l}\text { Rely on evacuation and } \\
\text { insurance to manage risk, } \\
\text { rather than fuel } \\
\text { management. } \\
\text { Governments support local } \\
\text { groups to educate people } \\
\text { about evacuation. }\end{array}$ \\
\hline $\begin{array}{c}\text { KEY } \\
\text { ASSUMPTIONS }\end{array}$ & $\begin{array}{l}\text { People who have participated } \\
\text { in fire risk education will } \\
\text { become self-directed. Self- } \\
\text { reliant people will make better } \\
\text { decisions regarding whether to } \\
\text { live in an area and toward } \\
\text { protecting their own properties } \\
\text { and lives from bushfire. }\end{array}$ & $\begin{array}{l}\text { Planning rules about } \\
\text { private development and } \\
\text { clearing, and planned } \\
\text { burning of public land near } \\
\text { towns will together reduce } \\
\text { instances of high fuel loads } \\
\text { near houses. This in turn } \\
\text { will reduce loss of } \\
\text { property and lives in } \\
\text { bushfires. }\end{array}$ & $\begin{array}{l}\text { Weed control and planned } \\
\text { burning for ecological } \\
\text { purposes will improve the } \\
\text { environment and will } \\
\text { reduce fuels to some } \\
\text { extent. People manage } \\
\text { their risk by evacuating, } \\
\text { rather than damaging the } \\
\text { natural environment. }\end{array}$ \\
\hline $\begin{array}{l}\text { MAIN } \\
\text { KNOWLEDGE } \\
\text { BASES }\end{array}$ & $\begin{array}{l}\text { Knowledge in local } \\
\text { communities about how } \\
\text { people learn about fire }\end{array}$ & $\begin{array}{l}\text { Bushfire science and risk } \\
\text { modeling (e.g., distance } \\
\text { from bush that puts houses } \\
\text { at risk) }\end{array}$ & $\begin{array}{l}\text { Ecological knowledge } \\
\text { (local and scientific) }\end{array}$ \\
\hline $\begin{array}{l}\text { SCALE AND } \\
\text { LOCATION }\end{array}$ & $\begin{array}{l}\text { Small local scale (own } \\
\text { property, neighbors, local } \\
\text { bushland that presents risk) }\end{array}$ & $\begin{array}{l}\text { Broad landscape scales } \\
\text { (risk is analyzed across the } \\
\text { landscape using scientific } \\
\text { principles) }\end{array}$ & $\begin{array}{l}\text { Community scale (e.g.; } \\
\text { rural locality) and public } \\
\text { land of ecological value }\end{array}$ \\
\hline
\end{tabular}

potential for this use. We presented the scenarios to different strategic planning and community engagement practitioners in the Department of Environment, Land, Water and Planning, and they were enthusiastically received as something that they could engage in their practice on exploring value tensions and exploring value-based conversations in a more tangible way with communities.

\section{EVALUATION OF THE SCENARIO SET}

To evaluate the value-based approach, the resulting set of scenarios was assessed based on the criteria underpinning the process, that is, on whether the set met three practical and social goals: (1) provision of a discrete set of alternatives (van Notten et al. 2003, Carpenter et al. 2005, Soliva 2007, Nordström et al. 2010); (2) fostering of discussion about values; and (3) relatability 
Fig. 6. Illustration for "developing self-reliant people and communities," one of the three scenarios refined from those developed in workshops that were shown to post-workshop interview participants.

\section{Developing self-reliant people and communities}

\author{
THE VISION \\ Individual responsibility and action \\ are paramount. \\ People act to protect their own families, homes, businesses and neighbours \\ from bushfire.
}

\section{MANAGEMENT ACTIONS \\ EDUCATION OF INDIVIDUALS FOR BUSHFIRE SAFETY \\ E local governments and emergency management groups support local education of individuals \\ E wide-spread formal education about: fire risks in local areas; choices about where people live; the experience of being in a fire; planning for evacuation; and the costs of recovery \\ INDIVIDUAL PLANNING AND PREPARATION \\ individuals plan and prepare for bushfires \\ a governments do not prevent people from making their own decisions about bushfire safety}

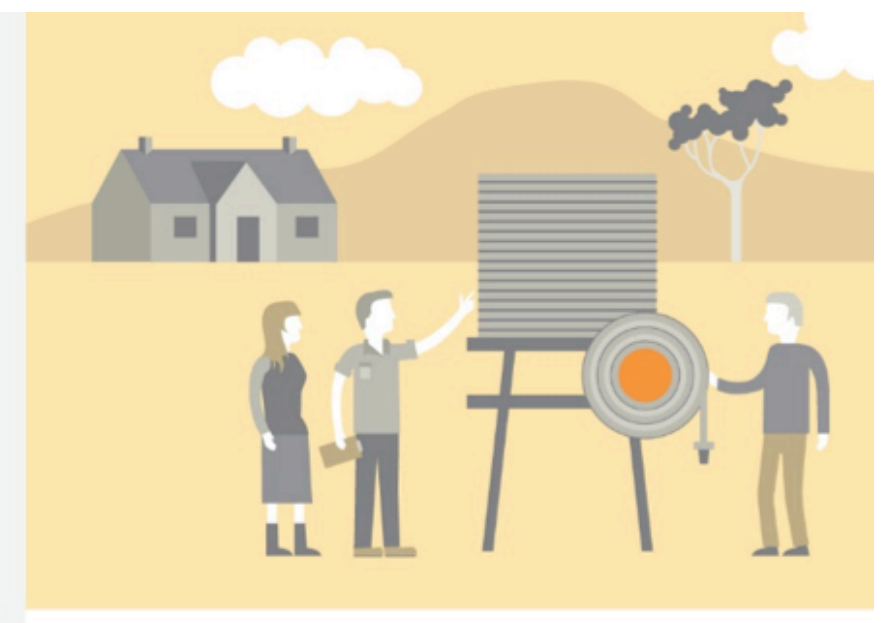

\section{EXPERT OPINIONS}

Protection of human lives MEDIUM

Protection of homes

Habitat for plants, birds and animals

Individual and community self-reliance
Low

MEDIUM

HIGH

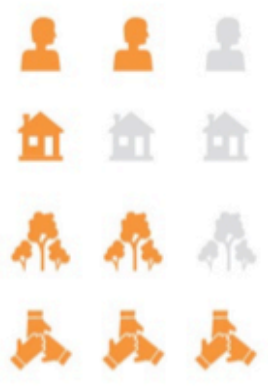

to scenario creators, government staff, and general members of the public.

We interviewed 10 members of the Victorian public who had not participated in the scenario development about their interpretation and perspectives of the scenario set in two different regions in Victoria: a periurban area close to Melbourne and one rural area in the northeast of the state. These individuals covered a diverse range in terms of age (from 20 s to 70 s), gender, property type, occupation, and experience with fire. During the workshops, it was challenging for us to recruit young people (under 40) to participate in the series. Particular attention was given to interviewing people aged 20 to 40 . We asked interview participants to rate the acceptability of each scenario along a scale of 1-7 and to explain their rating. Participants compared the scenarios and discussed tensions that the scenarios brought up for them. Interviews lasted 30-60 minutes and were audio-recorded and transcribed. Data were analyzed using qualitative thematic analysis (Boeije 2010).

Three distinct and comparable scenarios enabled consideration of how abstract values are explicitly visualized in possible, broad natural disaster management approaches (Fig. 5). These scenarios are "developing self-reliant people and communities"; "a safe society: separating people and fuel"; and "living with nature and bushfire." Figures 6, 7, and 8 illustrate each scenario. The scenarios were intentionally polarized; none of them were perfect to participants, but there were aspects of each that they liked, disliked, and that made them reflect on uncomfortable priorities and management actions. For example, one interview participant was uncomfortable with "a safe society" because of the lack of focus on the environment, which was important to him: "You cannot choose to live in the bush and then chop it all down to make it safe. It makes me upset. Why live there if that's what you want to do?" Another was uncomfortable with the scenario "living with nature and bushfire," because it put too little priority on the protection of human life and well-being, which was important to her: "I am uncomfortable with the plan that people will be able to make decisions in the event of fire and that they could just lose everything."

The scenarios fostered discussion, which enabled participants to make interesting links between abstract and more tangible values and management actions. Quotes have been drawn from both workshop transcripts and responses to the social acceptability questionnaire in workshop 3. For example, participants building "developing self-reliant people and communities" (a scenario underpinned by self-direction) considered education to be a key management action that would enable residents to act on their own behalf: "[Education is] most likely the best available options to protect their own homes, family and neighbors" (workshop participant 1). "Education and awareness. Ultimately you can't tell people what to do in a circumstance. You can offer guidance 
Fig. 7. Illustration for "a safe society: separating people and fuel," one of the three scenarios refined from those developed in workshops that were shown to post-workshop interview participants.

\section{A safe society: separating people and fuel}

\section{THE VISION \\ All of human society is paramount. \\ State and local governments act to protect people, property and infrastructure from bushfire.}

\section{MANAGEMENT ACTIONS}

\section{PEOPLE PROTECTED FROM LIVING IN HIGH RISK AREAS}

a governments make planning rules to limit development in risky areas

In governments buy back properties

= real estate agents inform buyers about fire risk

\section{BURNING AND CLEARING OF VEGETATION}

= governments do regular planned burning near towns

= people are allowed to clear near houses

GOVERNMENT PLANNING FOR EVACUATION

In roads to be used in evacuations are improved

E governments communicate about current fires
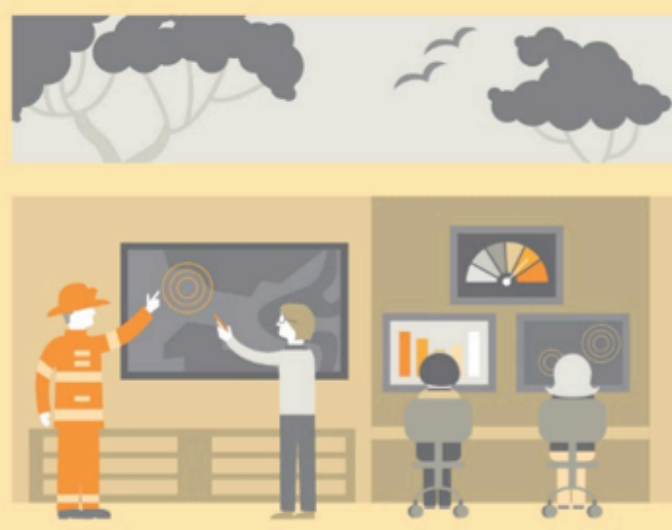

\section{EXPERT OPINIONS}

Protection of human lives

Protection of homes

Habitat for plants, birds

and animals

Individual and

community self-reliance
HIGH

HIGH

LOW
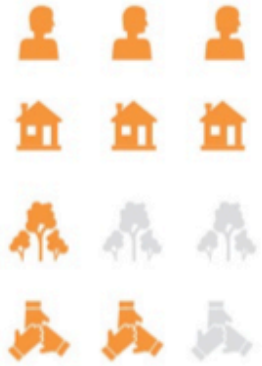

or help them think" (workshop participant 9). For participants developing "a safe society" (a scenario underpinned by security), limiting development and vegetation management (primarily planned burning) would prevent the occurrence of bushfire: "There should be a moratorium on further development" (workshop participant 7). "Limit development in high risk parts of landscape 'a must"” (workshop participant 4). "Burning on public land is good where there is public land adjacent to assets" (workshop participant 5). The value-based scenario development process enabled participants to meaningfully consider how values shape bushfire planning and management approaches.

The scenarios created discomfort, which enabled people who engaged with the predeveloped scenarios to explore and communicate about otherwise intangible value tensions. Interview participant 2 stated that prioritizing society over the environment in "a safe society" made him uncomfortable but that this was also interesting to reflect on abstractly: "This scenario upsets me. ... it is not good for the environment ... but it's good to talk about and compare." Interview participant 3 said that the scenarios were an interesting way of comparing and considering ways of thinking about bushfire that she would not have been able to otherwise consider if the values and management actions had not been described as scenarios: "You don't often get a chance to think like this about fire and the people in the place." Interview participant 10 stated that "no government should have as much control" as is given in "a safe society," and if it did, it would make him very uncomfortable, because his experience is that the government cannot make the best on-the-ground decisions. He stated that in a recent fire "government workers were sent to protect a historic site, while a family burned alive just a couple kilometers up the road" (interview participant 10). Interview participant 5, a farmer, talked about his focus on protecting human life in the event of a fire and on supporting environmental integrity in the day to day; however, "living with nature and bushfire" was unethical in his view, in protecting only the environment. A participant who worked in an emergency department and who lived on a farm said that enabling people to make their own decisions in the scenario "developing self-reliant people and communities" made her deeply uncomfortable because "ultimately people cannot be trusted to make good decisions in emergency situations; people are dumb" (interview participant 9). "There are parts of all of them that I like and dislike. Some things, like the environment being first makes me uncomfortable. A balance is needed. It's good to think about" (interview participant 8). Rarely do people get the chance to consider multiple, distinctly different approaches to management, and comparing these three scenarios allowed people to consider what was important to them and how the scenarios complimented or conflicted with that. 
Fig. 8. Illustration for "living with nature and bushfire," one of the three scenarios refined from those developed in workshops that were shown to post-workshop interview participants.

\title{
Living with nature and bushfire
}

\author{
THE VISION
}

\section{Environmental integrity is paramount.}

Governments, local groups and individuals manage ecosystems.

Fire is a natural part of the environment.

\section{MANAGEMENT ACTIONS}

\section{EVACUATION, INSTEAD OF MODIFYING NATURE}

E individuals manage bushfire risk by evacuating on fire risk days

= individuals choose the risk of property loss, rather than modifying the natural environment

a governments support local groups (e.g. Community Fireguard) to help people plan for evacuations

ENVIRONMENTAL MANAGEMENT FOR WILDLIFE, NOT FOR REDUCING BUSHFIRE FUELS

a governments, local groups and individuals manage the environment to benefit native wildlife (e.g. weeding)

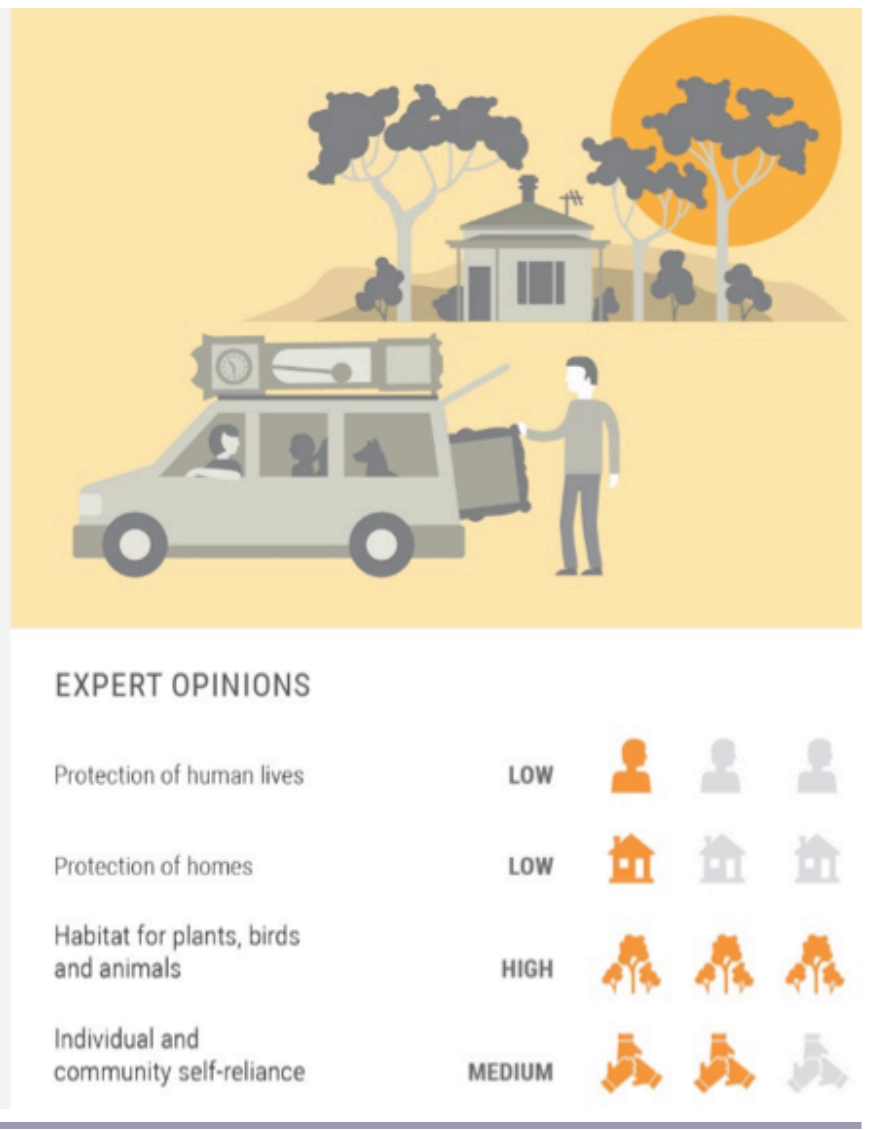

The scenarios were meaningful and effective as a heuristic for reflection because participants were able to make sense of them through relating them to their own lived experience. For example, interview participant 3 said that each of the scenarios was not ideal because of her experience with previously living in a bushfire prone landscape and from having lived through a fire: "I think about and judge these [scenarios] based on my experience ... many people who say they are experts are not actually, because they haven't lived in a community and lived through fire." As such, the interviews highlighted that some people reject expert knowledge. She expressed how community is not always a caring, supportive network when it comes to needing others in a time of emergency, as implied in "developing self-reliant people and communities": "The scenario sounds great on paper, but we experienced being rejected by our community in the fire." Interview participant 1 related the scenarios to his experience: "This [developing selfreliant people and communities] is very similar to how things are done now. People are responsible for themselves, but that isn't really effective." Having scenarios that grappled with values and value tensions that were created by members of the public meant that the narrative of them was relatable to the day-to-day, lived experience of other members of the public.

\section{DISCUSSION}

Exploring and comparing values and value tensions in planning and management for social-ecological contexts was effective through the use of scenarios. People relate to a discussion of values through scenarios. Although people make sense of the world through stories (Soliva 2007), our findings show that the structured relationship between values underpinning the three scenarios becomes useful in interpreting the discomforts, preferences, and beliefs expressed. Sharp differences or comparisons and, in our research, "no ideal" scenarios cause the disruption that Weick (2001) suggests provokes sense making. Sense making occurs as participants draw on and relate their own experience and stories from their world to consider the strengths and weaknesses of each scenario. Although contrasting scenarios are not unique (e.g., Carpenter et al. 2005, Rawluk and Godber 2011, Low Choy et al. 2012), the generation of these scenarios as directly value driven using a robust conceptual framework for values sets these apart from other participatory scenarios. Valuebased scenarios enable a transparent and conceptually robust exploration of how abstract and concrete values relate in everyday life and of alternative ways of approaching natural disaster management through a value lens.

Our scenarios resonate with themes of how things should be protected in bushfire environmental discourses (Whittaker and Mercer 2004) and bushfire management framings (Bosomworth 2011). The conservationist environmental discourse (Whittaker and Mercer 2004), wherein bushfire is natural and inevitable, resonates in the "living with nature and bushfire" scenario where the environment is of the utmost importance and must be 
protected and people must adapt to the unpredictability of bushfire in the landscape. The scenarios "developing self-reliant people and communities" and "a safe society," with the focus on protecting human life and property, echoed the ruralist and wiseuse environmental discourses (Whittaker and Mercer 2004). "A safe society" was echoed in Bosomworth (2011), who found an organizational framing that promoted the protection of human life by planned burning, rapid response in the event of emergency, and land use planning that removed people from high-risk areas. Although supporting the findings of Whittaker and Mercer (2004) and Bosomworth (2011), our developed scenarios also extend knowledge by providing clearer understanding of the values that underpin these discourses.

We suggest that developing and reflecting on scenarios reveals discomfort associated with value conflict. We encountered this with both workshop participants and interview participants when asked to reflect on predeveloped scenarios. This builds on Ramírez and Selin (2014) who state that scenarios can be used to create discomfort in terms of possible futures. Value-based scenarios not only cause discomfort, but additionally provide a structure in which to articulate and analyze the basis for discomfort in relation to what is important. Value-based scenarios then offer a way to discuss these tensions and look at complementarities and conflicts more directly than is often possible. Creating and considering scenarios in which no one scenario is ideal provokes conversation and discussion of tensions between scenarios as opposed to finding one that most aligns with a person's own values.

We take a first explicit step in addressing the call to integrate values in participatory scenarios (Oteros-Rozas et al. 2015) and have learned useful lessons from our experience of trying to combine values and PSP to suggest areas for improvement in future uses. First, participants needed to explore and discuss values in-depth to make sense of what these concepts were and how they related to their everyday experience and perspectives. Devoting the time needed to orient to and explore values is a particular challenge. Although we devoted the entire first workshop to exploring and understanding values, participants told us that they could have used even longer to engage with these ideas. Even at the end of the three workshops, they said that they could have used even longer to understand values. This leads to a second, contrasting challenge with the process: It was difficult for participants to commit to a series of three workshops and to come to each of them. Third, participants reported needing to reorient to the concept of values at the beginning of each workshop, because it was not a concept that they used in their day-to-day life in between the workshops. We recommend holding workshops close in time to one another to retain the coherence of the workshop series. Fourth, the decision to not include the combination of social altruism and self-direction (Fig. 3) was made during the pretesting phase of scenario development. Participants expressed difficulty in how to consider forms of individual action that would protect all of society. As such, we did not include it because of the seeming infeasibility of the scenario and because we were cognizant of the time constraints of workshop participants. However, we have since wondered what interesting reflections might have come from the combination of these two values and suggest that there may be merit in not limiting the development of scenarios. Finally, the qualitative research and pretesting that preceded the scenario development process were both critical to enabling that this went smoothly.
Despite the challenges in developing the scenarios, they were usable and understandable to workshop participants and members of the public, as explored through semistructured interviews and a survey (Williams et al. 2017). Our findings suggest that value-based scenarios could have utility as a community engagement tool. The value-based scenario framework and resulting scenarios allowed participants to reflect on their own values and how they differ from others. Participants observed how their values might be reflected in decision making or how they are not reflected and the complexity of bushfire policy and planning. Further, people related to and found accessible the narrative and illustration as a means for expressing the scenario. It allowed them to think about what was important to them or the management actions that they considered to be appropriate without actually having to consider the academic use of values that underpinned them. Additionally, we demonstrate the importance of recognizing the needs of the audience in presenting the scenarios, acknowledging that for some the narratives were compelling and relatable, while for others expert knowledge was scrutinized.

\section{CONCLUSION}

We proposed and utilized a value-based framework for developing contrasting, participatory natural disaster management scenarios in the context of bushfire. Value-based scenarios can support understanding relationships between values and approaches to natural disaster and enable creative exploration beyond participants' areas of comfort. Although the value-based scenarios successfully allowed values to be untangled and visualized in approaches to natural disaster management, the research provides an opportunity for exploring future questions. Further research might explore how communities and policy makers can come together to find an ideal scenario for approaching natural disaster management. Research is needed on how to balance the core values that underpinned the scenarios for application to policy and planning. As management and policy making around the world begin to shift to greater community involvement in decision making and transparent consideration of public values, and the risk and impacts of natural disaster seem only to pose greater threat, the answers to these questions will be of increasing importance for generations to come.

\section{Responses to this article can be read online at: http://www.ecologyandsociety.org/issues/responses. php/10447}

\section{Acknowledgments:}

We wish to thank the Department of Environment, Land, Water and Planning for the funding that supported this research and the staff support of Sanchia Draper and Kathy Overton (the Department of Environment, Land, Water and Planning) and Adam Whitchurch (Parks Victoria) in conducting the research. We are very grateful for the participants from Victoria that developed these scenarios and for the invaluable input from Zuzana Harmackova on an earlier draft of the manuscript. We thank two anonymous reviewers for their invaluable feedback that improved the paper. Figures 6-8 were prepared by Blue Vapours Creative Studios. 


\section{LITERATURE CITED}

Altangerel, K., and C. A. Kull. 2013. The prescribed burning debate in Australia: conflicts and compatibilities. Journal of Environmental Planning and Management 56(1):103-120. http:// dx.doi.org/10.1080/09640568.2011.652831

Bennett, E. M., M. Solan, R. Biggs, T. McPhearson, A. V. Norström, P. Olsson, L. Pereira, G. D. Peterson, C. RaudseppHearne, F. Biermann, S. R. Carpenter, E. C. Ellis, T. Hichert, V. Galaz, M. Lahsen, M. Milkoreit, B. M. López, K. A. Nicholas, R. Preiser, G. Vince, J. M. Vervoort, and J. Xu. 2016. Bright spots: seeds of a good Anthropocene. Frontiers in Ecology and the Environment 14(8):441-448. http://dx.doi.org/10.1002/fee.1309

Biggs, R., C. Raudsepp-Hearne, C. Atkinson-Palombo, E. Bohensky, E. Boyd, G. Cundill, H. Fox, S. Ingram, K. Kok, S. Spehar, M. Tengö, D. Timmer, and M. Zurek. 2007. Linking futures across scales: a dialog on multiscale scenarios. Ecology and Society 12(1):17. http://dx.doi.org/10.5751/ES-02051-120117

Boeije, H. 2010. Analysis in qualitative research. Sage, London, UK.

Bosomworth, K. A. 2011. Adaptive governance in fire management: exploring the role of bureaucrats in reflexive learning. Dissertation. RMIT University, Melbourne, Victoria, Australia.

Bourne, H., and M. Jenkins. 2005. Eliciting managers' personal values: an adaptation of the laddering interview method. Organizational Research Methods 8(4):410-428. http://dx.doi. org/10.1177/1094428105280118

Brown, T. C. 1984. The concept of value in resource allocation. Land Economics 60:231-246. http://dx.doi.org/10.2307/3146184

Brown, G., and P. Reed. 2000. Validation of a forest values typology for use in national forest planning. Forest Science 46:240-247.

Carlsen, H., K. H. Dreborg, and P. Wikman-Svahn. 2013. Tailormade scenario planning for local adaptation to climate change. Mitigation and Adaptation Strategies for Global Change 18:1239-1255. http://dx.doi.org/10.1007/s11027-012-9419-x

Carpenter, S. R., P. L. Pingali, E. M. Bennett, and M. B. Zurek, editors. 2005. Ecosystems and human well-being: scenarios. Findings of the Scenarios Working Group of the Millennium Ecosystem Assessment. Island, Washington, D.C., USA.

Curry, A., and W. Schultz. 2009. Roads less travelled: different methods, different futures. Journal of Futures Studies 13(4):35-60.

Denhardt, J. V., and R. B. Denhardt. 2000. The new public service: serving, not steering. M. E. Sharpe, New York, New York, USA.

Department of Sustainability and Environment. 2012. Code of practice for bushfire management on public land. State Government Victoria, Melbourne, Victoria, Australia. [online] URL: https:// www.ffm.vic.gov.au/ data/assets/pdf_file/0025/25747/Code-of-Practicefor-Bushfire-Management-on-Public-Land-1.pdf

Enfors, E. I., L. J. Gordon, G. D. Peterson, and D. Bossio. 2008. Making investments in dryland development work: participatory scenario planning in the Makanya catchment, Tanzania. Ecology and Society 13(2):42. http://dx.doi.org/10.5751/ES-02649-130242
Evans, K., S. J. Velarde, R. Prieto, S. N. Rao, S. Sertzen, K. Dávila, P. Cronkleton, and W. de Jong. 2006. Field guide to the future: four ways for communities to think ahead. E. Bennett and M. Zurek, editors. Center for International Forestry Research, Jakarta, Indonesia; ASB and World Agroforestry Centre, Nairobi, Kenya. [online] URL: http://www.asb.cgiar.org/ PDFwebdocs/Evans-et-al-2006-Field-guide-to- the-future.pdf

Ford, R. M., N. M. Anderson, C. Nitschke, L. T. Bennett, and K. J. H. Williams. 2017. Psychological values and cues as a basis for developing socially relevant criteria and indicators for forest management. Forest Policy and Economics 78:141-150. http://dx. doi.org/10.1016/j.forpol.2017.01.018

Ford, R. M., K. J. H Williams, I. D. Bishop, and T. Webb. 2009. A value basis for the social acceptability of clearfelling in Tasmania, Australia. Landscape and Urban Planning 90:196-206. https://doi.org/10.1016/j.landurbplan.2008.11.006

Ford, R. M., K. J. H. Williams, E. L. Smith, and I. D. Bishop. 2014. Beauty, belief, and trust: toward a model of psychological processes in public acceptance of forest management. Environment and Behavior 46:476-506. https://doi.org/10.1177\% $\underline{\text { 2F0013916512456023 }}$

Gill, A. M. 2012. Bushfires and biodiversity in southern Australian forests. Pages 235-252 in R. A. Bradstock, R. J. Williams, and A. M. Gill, editors. Flammable Australia: fire regimes, biodiversity and ecosystems in a changing world. CSIRO, Collingwood, Victoria, Australia.

Graham, S., J. Barnett, R. Fincher, A. Hurlimann, C. Morteux, and E. Waters. 2013. The social values at risk from sea-level rise. Environmental Impact Assessment Review 41:45-52. http://dx.doi. org/10.1016/j.eiar.2013.02.002

Gregory, R., and R. L. Keeney. 1994. Creating policy alternatives using stakeholder values. Management Science 40(8):1035-1048. http://dx.doi.org/10.1287/mnsc.40.8.1035

Jones, N. A., S. Shaw, H. Ross, K. Witt, and B. Pinner. 2016. The study of human values in understanding and managing socialecological systems. Ecology and Society 21(1):15. http://dx.doi. org/10.5751/ES-07977-210115

Kendal, D., R. M. Ford, N. M. Anderson, and A. Farrar. 2015. The VALS: a new tool to measure people's general valued attributes of landscapes. Journal of Environmental Management 163:224-233. http://dx.doi.org/10.1016/j.jenvman.2015.08.017

Kok, K., D. S. Rothman, and M. Patel. 2006. Multi-scale narratives from an IA perspective: Part I. European and Mediterranean scenario development. Futures 38:261-284. http:// dx.doi.org/10.1016/j.futures.2005.07.001

Larsen, K., and U. Gunnarsson-Östling. 2009. Climate change scenarios and citizen-participation: mitigation and adaptation perspectives in constructing sustainable futures. Habitat International 33(3):260-266. http://dx.doi.org/10.1016/j. habitatint.2008.10.007

Larsen, K., U. Gunnarsson-Östling, and E. Westholm. 2011. Environmental scenarios and local-global level of community engagement: environmental justice, jams, institutions and 
innovation. Futures 43:413-423. http://dx.doi.org/10.1016/j. futures.2011.01.007

Lindesay, J. A. 2003. Fire and climate in Australia. Pages 32-40 in G. Cary, D. Lindenmayer, and S. Dovers, editors. Australia burning: fire ecology, policy and management issues. CSIRO, Collingwood, Victoria, Australia.

López-Mosquera, N., and M. Sánchez. 2011. The influence of personal values in the economic-use valuation of peri-urban green spaces: an application of the means-end chain theory. Tourism Management 32(4):875-889. http://dx.doi.org/10.1016/j. tourman.2010.08.003

Low Choy, D., S. Serrao-Neumann, F. Crick, G. Schuch, M. Sanò, R. van Staden, O. Sahin, B. Harman, and S. Baum. 2012. Scenario planning for climate change adaptation. South East Queensland Climate Adaptation Research Initiative, Griffith University, Nathan, Queensland, Australia.

Malinga, R., L. J. Gordon, R. Lindborg, and G. Jewitt. 2013. Using participatory scenario planning to identify ecosystem services in changing landscapes. Ecology and Society 18(4):10. http://dx.doi.org/10.5751/ES-05494-180410

Mason, M. 2010. Sample size and saturation in PhD studies using qualitative interviews. Forum: Qualitative Social Research Sozialforschung 11(3):1-19.

Mitchell, M., M. Lockwood, S. A. Moore, S. Clement, L. Gilfedder, and G. Anderson. 2016. Using scenario planning to assess governance reforms for enhancing biodiversity outcomes. Land Use Policy 50:559-572. http://dx.doi.org/10.1016/j. landusepol.2015.10.020

Moritz, M. A., E. Batllori, R. A. Bradstock, A. M. Gill, J. Handmer, P. F. Hessburg, J. Leonard, S. McCaffrey, D. C. Odion, T. Schoennagel, and A. D. Syphard. 2014. Learning to coexist with wildfire. Nature 515:58-66. http://dx.doi.org/10.1038/ $\underline{\text { nature } 13946}$

Nieto-Romero, M., A. Milcu, J. Leventon, F. Mikulcak, and J. Fischer. 2016. The role of scenarios in fostering collective action for sustainable development: lessons from central Romania. Land Use Policy 50:156-168. http://dx.doi.org/10.1016/j.landusepol.2015.09.013

Nordström, E.-M., L. O. Eriksson, and K. Öhman. 2010. Integrating multiple criteria decision analysis in participatory forest planning: experience from a case study in northern Sweden. Forest Policy and Economics 12:562-574. http://dx.doi. org/10.1016/j.forpol.2010.07.006

O'Brien, K. L. 2009. Do values subjectively define the limits to climate change adaptation? Pages 164-180 in W. N. Adger, I. Lorenzoni, and K. L. O'Brien. Adapting to climate change: thresholds, values, governance. Cambridge University Press, Cambridge, UK. http://dx.doi.org/10.1017/CBO9780511596667.011

O’Neill, S. J., and J. Handmer. 2012. Responding to bushfire risk: the need for transformative adaptation. Environmental Research Letters 7:1-7. http://dx.doi.org/10.1088/1748-9326/7/1/014018

Oteros-Rozas, E., B. Martín-López, T. Daw, E. L. Bohensky, J. Butler, R. Hill, J. Martin-Ortega, A. Quinlan, F. Ravera, I. RuizMallén, M. Thyresson, J. Mistry, I. Palomo, G. D. Peterson, T. Plieninger, K. A. Waylen, D. Beach, I. C. Bohnet, M. Hamann,
J. Hanspach, K. Hubacek, S. Lavorel, and S. Vilardy. 2015. Participatory scenario planning in place-based social-ecological research: insights and experiences from 23 case studies. Ecology and Society 20(4):32. http://dx.doi.org/10.5751/ES-07985-200432

Palomo, I., B. Martín-López, C. López-Santiago, and C. Montes. 2011. Participatory scenario planning for protected areas management under the ecosystem services framework: the doñana social-ecological system in southwestern Spain. Ecology and Society 16(1):23. http://dx.doi.org/10.5751/ES-03862-160123

Parliament of Victoria. 2010. Final report: 2009 Victorian Bushfires Royal Commission. Government Printer for the State of Victoria, Melbourne, Victoria, Australia. http://royalcommission. vic.gov.au/finaldocuments/summary/HR/VBRC_Summary_HR. pdf

Patel, M., K. Kok, and D. S. Rothman. 2007. Participatory scenario construction in land use analysis: an insight into the experiences created by stakeholder involvement in the Northern Mediterranean. Land Use Policy 24:546-561. http://dx.doi. org/10.1016/j.landusepol.2006.02.005

Peterson, G. D., G. S. Cumming, and S. R. Carpenter. 2003. Scenario planning: a tool for conservation in an uncertain world. Conservation Biology 17(2):358-366. http://dx.doi.org/10.1046/ j.1523-1739.2003.01491.X

Ramírez, R., and C. Selin. 2014. Plausibility and probability in scenario planning. Foresight 16(1):54-74. https://doi.org/10.1108/ FS-08-2012-0061

Rawluk, A., R. M. Ford, F. L. Neolaka, and K. J. Williams. 2017. Public values for integration in natural disaster management and planning: a case study from Victoria, Australia. Journal of Environmental Management 185:11-20. http://dx.doi.org/10.1016/ j.jenvman.2016.10.052

Rawluk, A., and A. Godber. 2011. Widening the scope of scenario planning in small communities: a case study use of an alternative method. Ecology and Society 16(1):11. [online] URL: http://www. ecologyandsociety.org/vol16/iss1/art11/

Rotmans, J., M. van Asselt, C. Anastasi, S. Greeuw, J. Mellors, S. Peters, D. Rothman, and N. Rijkens. 2000. Visions for a sustainable Europe. Futures 32:809-831. http://dx.doi.org/10.1016/ $\underline{\text { S0016-3287(00)00033-1 }}$

Schwartz, S. H. 2012. An overview of the Schwartz theory of basic values. Online Readings in Psychology and Culture 2:1-18. http://dx.doi.org/10.9707/2307-0919.1116

Sheppard, S. R. J. 2005. Landscape visualisation and climate change: the potential for influencing perceptions and behaviour. Environmental Science \& Policy 8:637-654. http://dx.doi. org/10.1016/j.envsci.2005.08.002

Smith, E. L., I. D. Bishop, K. J. H. Williams, and R. M. Ford. 2012. Scenario Chooser: an interactive approach to eliciting public landscape preferences. Landscape and Urban Planning 106 (3):230-243. http://dx.doi.org/10.1016/j.landurbplan.2012.03.013

Soliva, R. 2007. Landscape stories: using ideal type narratives as a heuristic device in rural studies. Journal of Rural Studies 23:62-74. http://dx.doi.org/10.1016/j.jrurstud.2006.04.004 
State Government Victoria. 2015. Safer together: a new approach to reducing the risk of bushfire in Victoria. State Government Victoria, Melbourne, Victoria, Australia. http://www.delwp.vic. gov.au/_data/assets/pdf_file/0004/319531/DELWP_SaferTogether FINAL 17Nov15.pdf

van Egmond, N. D., and H. J. M. de Vries. 2011. Sustainability: the search for the integral worldview. Futures 43(8):853-867. http://dx.doi.org/10.1016/j.futures.2011.05.027

van Notten, P. W. F., J. Rotmans, M. B. A. van Asselt, and D. S. Rothman. 2003. An updated scenario typology. Futures 35:423-443. http://dx.doi.org/10.1016/S0016-3287(02)00090-3

Weick, K. E. 2001. Making sense of the organization. Blackwell, Malden, Massachusetts, USA.

Whittaker, J., K. Haynes, J. Handmer, and J. McLennan. 2013. Community safety during the 2009 Australian 'Black Saturday' bushfires: an analysis of household preparedness and response. International Journal of Wildland Fire 22:841-849. http://dx.doi. org/10.1071/WF12010

Whittaker, J., and D. Mercer. 2004. The Victorian bushfires of 2002-03 and the politics of blame: a discourse analysis. Australian Geographer 35(3):259-287. http://dx.doi.org/10.1080/000491804$\underline{2000311313}$

Williams, K. J., R. M. Ford, and A. Rawluk. 2017. Strategies and tools for incorporating values of the Victorian public in strategic bushfire risk decision making. University of Melbourne, Melbourne, Victoria, Australia.

Xiang, W.-N., and K. C. Clarke. 2003. The use of scenarios in land-use planning. Environment and Planning B: Urban Analytics and City Science 30:885-909. http://dx.doi.org/10.1068/b2945 